\title{
THE MATHEMATICAL MODELLING OF THE PRODUCTION OF CONSTRUCTION MIXTURES WITH PRESCRIBED PROPERTIES
}

\author{
A.L. Shestakov, South Ural State University, Chelyabinsk, Russian Federation, \\ admin@susu.ac.ru, \\ G.A. Sviridyuk, South Ural State University, Chelyabinsk, Russian Federation, \\ sviridyuk@susu.ac.ru, \\ M.D. Butakova South Ural State University, Chelyabinsk, Russian Federation, \\ butakovamd@susu.ac.ru
}

\begin{abstract}
We propose a method for the mathematical modelling of the preparation of construction mixes with prescribed properties. The method rests on the optimal control theory for Leontieff-type systems. Leontieff-type equations originally arose as generalizations of the well-known input-output model of economics taking supplies into account. Then they were used with success in dynamical measurements, therefore giving rise to the theory of optimal measurements.

In the introduction we describe the ideology of the proposed model. As an illustration, we use an example of preparing of simple concrete mixes. In the first section we model the production process of similar construction mixtures (for instance, concrete mixtures) depending on investments. As a result, we determine the price of a unit of the product. In the second section we lay the foundation for the forthcoming construction of numerical algorithms and software, as well as conduction of simulations. Apart from that, we explain the prescribed properties of construction mixes being optimal with respect to expenses.

Ключевые слова: Leontieff-type system; production of construction mixes.
\end{abstract}

\section{Introduction}

Take two square matrices $L$ and $M$ of size $n$, allowing $\operatorname{det} L=0$. The system of ordinary differential equations

$$
L \dot{x}=M x+u
$$

is called a Leontieff-type system. For the first time system (1) appeared as a generalization of Leontieff input-output economical model taking supplies into account [1]. It was used to calculate the municipal economy of the town of Emanzhelinsk in Chelyabinsk region [2]. Subsequently the Leontieff-type equations theory advanced [3]; numerical algorithms were developed [4], software was constructed [5]. Eventually the results merged into the optimal control theory of Leontieff-type models [6]. This theory received a new impetus for development when it was adapted to the needs of dynamical measurements theory [7]. The foundations of the resulting optimal measurements theory are laid in [8], the first survey of its results appeared in [9], and a direction for its further development is proposed in [10]. Both theories rest on the Sobolev-type equations theory, which addresses the equations of the form (1) in infinite-dimensional Banach spaces. Some of the first publications concerning this theory were [11,12]. Presently the number of books dealing with this theory is snowballing; let us just mention [13-22]. In addition, the Sobolev-type equations theory is already extended from Banach spaces to Fréchet spaces [23], and now it is being 
carried over to quasi-Banach spaces [24]. Finally, note also the closely related theory of algebro-differential systems $[25,26]$ with all its numerous offshoots.

Start with considering of an example of preparing a simple concrete mix. It requires: water $x_{1}$, sand $x_{2}$, gravel $x_{3}$, concrete $x_{4}$. In addition, we need electricity $x_{5}$ to rotate the mixer as well as labor $x_{6}$ to combine everything. We can express the first four components either in mass units (tonnes for instance) or in spatial units (cubic meters for instance). The last two components cannot be measured in those units, however, we can express all components in terms of their cost. Following the approach of Leontieff, we represent the expenses to make concrete as the system of equations

$$
A \dot{x}+B x=u,
$$

where $A$ and $B$ are square matrices of size 6 whose entries characterize the capital and current expenses to produce six variants of some grade of concrete. For instance,

$$
\sum_{k=1}^{6} a_{1 k} \dot{x}_{k}+\sum_{k=1}^{6} b_{1 k} x_{k}=u_{1}
$$

are the total expenses to produce some standard grade of concrete. To produce other variants of the same grade, we want to use different equipment and take twice as much water. We obtain

$$
\sum_{k=1}^{6} a_{2 k} \dot{x}_{k}+2 b_{11} x_{1}+\sum_{k=2}^{6} b_{1 k} x_{k}=u_{2} .
$$

Thus, varying the entries of $A$ and $B$, we can, by way of system (2), consider the production of six virtual variants of some grade of concrete.

Observe that for $n=6$ system (2), up to changing notation and permutations, coincides with system (1), which we put down as the foundation of our mathematical model of production of construction mixes. This means, in particular, that we can increase without any limit the number of virtual construction mixtures, introducing additional components like, for instance, additives, catalyzers, inhibitors, and so on. Note also that the construction of matrices $L$ and $M$ is a problem of economics engineering, whose solution we leave outside the scope of this article. Henceforth we assume this problem to be solved; we emphasize only that necessarily $\operatorname{det} L=0$ since the last column of $L$, following the tradition going back to Leontief, corresponds to capital investments into labor and contains only zeroes.

Thus, system (1) is the basis of the mathematical model of construction mixes production. We consider solutions $x=x(t)$ on the interval $[0, \tau]$ with $\tau \in \mathbb{R}_{+}$. Each solution is a vector function $x=\left(x_{1}, x_{2}, \ldots, x_{n}\right)$; each component $x_{k}=x_{k}(t)$ for $k=1,2, \ldots, n$ and $t \in[0, \tau]$, corresponds to a component of the construction mix. The vector function $u=u(t)$ of $t \in[0, \tau]$ in the right-hand side of (1) stands for the financial expenses to produce the construction mix, in particular, its component $u_{k}=u_{k}(t)$ for $k=1,2, \ldots, n$ and $t \in[0, \tau]$, stands for the expenses required to produce the (virtual) variant $k$ of the construction mix. It may seem that as the parameter $t \in[0, \tau]$, which in our model corresponds to time, grows, the expenses $u_{k}=u_{k}(t)$ can only increase. However, in reality this is not so. For instance, to speed up the process, at some moment of time $t_{1} \in(0, \tau)$ we add a certain expensive catalyzer (for instance, gold) and remove it after some time at the moment $t_{1}+\Delta t \in(0, \tau)$. Clearly, at the moment $t_{1}$ the expenses sharply increase, and at the moment $t_{1}+\Delta t$ they fall just as sharply. 
We may assume that in the beginning of the production (that is, at $t=0$ ) a number of components of the construction mix are already available (although this is not necessary). Thus, we should complement system (1) with the Cauchy initial conditions $x(0)=x_{0}$ (actually, we can take $x_{0}=0$ ). However, it has been observed [27] that for Sobolevtype equations, and for Leontieff-type systems (1) as their particular case, the ShowalterSidorov initial condition

$$
P\left(x(0)-x_{0}\right)=0
$$

is more natural, where $P$ is a projector matrix constructed from $L$ and $M$. Incidentally, condition (3) is preferable to the Cauchy condition $[4,6]$ in simulations as well. In the first section we present our results on the solvability of problem (1), (3) as rigorously as possible.

In the second part of this article we explain how we understand the prescribed properties of construction mixes. Since the proposed mathematical model comes from economics, by the prescribed properties we mean the optimization of financial expenses to produce the construction mixes. In other words, we are interested in the minimal cost we are ready to pay to obtain the construction mix of certain composition. We emphasize that in this article we just lay the foundation for a subsequent construction of numerical algorithms and software, as well as conduction of simulations. It is clear that this foundation requires powerful mathematics, which we borrow from both optimal control theory [6] and optimal measurements theory [9]. We are not planning to cover all possible situations immediately, but hope to have discussions with the experts in construction mixtures to improve our mathematical models.

The authors are grateful to A. V. Keller, A. A. Zamyshlyaeva, and M. A. Sagadeeva for their suggestions which helped to improve this article, and to S. A. Zagrebina and N. A. Manakova, whose work gave this article an almost ideal form. We ask the readers to address all praise to the first author, who initiated this study, and all critique to the other two authors.

\section{Mathematical Modelling of the Production of Construction Mixtures}

Take two square matrices $L$ and $M$ of size $n$. The matrix $M$ is called regular with respect to $L$ (or briefly, $L$-regular) whenever there exists a number $\alpha \in \mathbb{C}$ such that $\operatorname{det}(\alpha L-M) \neq$ 0 . If $M$ is $L$-regular then there exists at most $n$ points $\left\{\mu_{1}, \mu_{2}, \ldots, \mu_{m}\right\} \subset \mathbb{C}$, with $m \leq n$, such that $\operatorname{det}\left(\mu_{k} L-M\right)=0$ for $k=1,2, \ldots, m$. Refer to the set $\sigma^{L}(M)=\left\{\mu_{1}, \mu_{2}, \ldots, \mu_{m}\right\}$ as an $L$-spectrum of $M$. Observe that if $\operatorname{det} L \neq 0$ then the $L$-spectrum of $M$ coincides with the spectra of both $L^{-1} M$ and $M L^{-1}$. Assuming now that $M$ is $L$-regular, choose the contour $\gamma=\{\mu \in \mathbb{C}:|\mu|=r\}$, where $r>\max \left\{\left|\mu_{1}\right|,\left|\mu_{2}\right|, \ldots,\left|\mu_{m}\right|\right\}$, and construct the matrices

$$
P=\frac{1}{2 \pi i} \int_{\gamma}(\mu L-M)^{-1} L d \mu, \quad Q=\frac{1}{2 \pi i} \int_{\gamma} L(\mu L-M)^{-1} d \mu
$$

Lemma 1.1. If $M$ is an L-regular matrix then

(i) $P^{2}=P$ and $Q^{2}=Q$,

(ii) $L P=Q L$ and $M P=Q M$. 
Theorem 1.1. If $M$ is an $L$-regular matrix then there exist matrices $L^{\prime}$ and $M^{\prime}$ such that $L^{\prime} L=P, L L^{\prime}=Q, M^{\prime} M=\mathbb{I}_{n}-P$, and $M M^{\prime}=\mathbb{I}_{n}-Q$.

Here and henceforth $\mathbb{I}_{n}$ denotes the size $n$ identity matrix. Proofs of both claims amount to finite-dimensional adaptations of the infinite-dimensional results of subsection 4.1 of [17], and so we omit them.

Furthermore, taking the contour $\gamma \subset \mathbb{C}$ as above, construct the matrix functions

$$
U^{t}=\frac{1}{2 \pi i} \int_{\gamma} R_{\mu}^{L}(M) e^{\mu t} d \mu, \quad F^{t}=\frac{1}{2 \pi i} \int_{\gamma} L_{\mu}^{L}(M) e^{\mu t} d \mu,
$$

where $R_{\mu}^{L}(M)=(\mu L-M)^{-1} L$ is the right, and $L_{\mu}^{L}(M)=L(\mu L-M)^{-1}$ is the left $L$ resolvent of $M$. Observe that the Riemann sums of both integrals converge uniformly on every compact subset of $\mathbb{C}$.

Theorem 1.2. If $M$ is an L-regular matrix then

(i) $U^{0}=P$ and $F^{0}=Q$,

(ii) $L U^{t}=F^{t} L$ and $M U^{t}=F^{t} M$ for all $t \in \mathbb{C}$,

(iii) $U^{s+t}=U^{s} U^{t}$ and $F^{s+t}=F^{s} F^{t}$ for all $s, t \in \mathbb{C}$.

Proofs of these claims are also adaptations of the results of subsection 4.4 of [17] to our situation, and so we omit them. It is interesting to look at these results from the classical viewpoint, see Ch. 12 of [28].

Theorem 1.3. If $M$ is an L-regular matrix then there exist nondegenerate square matrices $A$ and $B$ of size $n$ such that

(i) $A L B=\left\{J_{n_{1}}, J_{n_{2}}, \ldots, J_{n_{k}}, \mathbb{I}_{r}\right\}$,

(ii) $A M B=\left\{\mathbb{I}_{n_{1}}, \mathbb{I}_{n_{2}}, \ldots, \mathbb{I}_{n_{k}}, N_{r}\right\}$.

Here $J_{n_{l}}$ for $l=1,2, \ldots, k$ are size $n_{l}$ Jordan blocks, $N_{r}$ are size $r$ square matrices,

$$
\sum_{l=1}^{k} n_{l}+r=n
$$

and the parentheses $\{$,$\} encode quasidiagonal matrices. Theorem 1.3$ follows easily from the results of Weierstrass, see [28], Ch.12, Section 3. Hence,

$$
\begin{gathered}
B^{-1} P B=\frac{1}{2 \pi i} \int_{\gamma} B^{-1}(\mu L-M)^{-1} A^{-1} A L B d \mu= \\
=\frac{1}{2 \pi i} \int_{\gamma}\left\{\left(\mu J_{n_{1}}-\mathbb{I}_{n_{1}}\right)^{-1},\left(\mu J_{n_{2}}-\mathbb{I}_{n_{2}}\right)^{-1}, \ldots,\left(\mu J_{n_{k}}-\mathbb{I}_{n_{k}}\right)^{-1},\left(\mu \mathbb{I}_{r}-N_{r}\right)^{-1}\right\} d \mu=\left\{\mathbb{O}_{n-r}, \mathbb{I}_{r}\right\}=\widetilde{P}
\end{gathered}
$$

since

$$
\left(\mu J_{n_{l}}-\mathbb{I}_{n_{l}}\right)^{-1}=-\mathbb{I}_{n_{l}}-\sum_{j=1}^{n_{l}} \mu^{j} J_{n_{l}}^{j}
$$

for $l=1,2, \ldots, k$. Similarly, $A^{-1} Q A=\left\{\mathbb{O}_{n-r}, \mathbb{I}_{r}\right\}=\widetilde{Q}$ and $A^{-1} U^{t} A=$ $\left\{\mathbb{O}_{n-r}, e^{t N_{r}}\right\}=\widetilde{U}^{t}=\widetilde{F}^{t}$. Here $\mathbb{O}_{n-r}$ is the zero size $n-r$ square matrix and

$$
e^{t N_{r}}=\sum_{k=0}^{\infty} \frac{t^{k} N_{r}^{k}}{k !}
$$


Furthermore, $L^{\prime}=B\left\{J_{n_{1}}^{n_{1}}, J_{n_{2}}^{n_{2}}, \ldots, J_{n_{k}}^{n_{k}}, \mathbb{I}_{r}\right\} A$. Indeed,

$$
L^{\prime} L=B\left\{J_{n_{1}}^{n_{1}}, J_{n_{2}}^{n_{2}}, \ldots, J_{n_{k}}^{n_{k}}, \mathbb{I}_{r}\right\} A A^{-1}\left\{J_{n_{1}}, J_{n_{2}}, \ldots, J_{n_{k}}, \mathbb{I}_{r}\right\} B^{-1}=B \widetilde{P} B^{-1}=P .
$$

In exactly the same fashion we obtain $L L^{\prime}=Q$. Similarly, $M^{\prime}=B\left\{\mathbb{I}_{n-r}, \mathbb{O}_{r}\right\} A$.

Consider now problem (1), (3). Refer to a vector function $x \in C\left([0, \tau] ; \mathbb{R}^{n}\right) \cap$ $C^{1}\left((0, \tau) ; \mathbb{R}^{n}\right)$ satisfying system (1) as a solution to this system (for some vector function $u=u(t))$. Call the solution $x=x(t)$ to (1) a solution to (1), (3) whenever it also satisfies condition (3) for some vector $x_{0} \in \mathbb{R}^{n}$.

Theorem 1.4. If $M$ is an L-regular matrix then for all $x_{0} \in \mathbb{R}^{n}$ and $u=u(t)$ such that $u^{0}=\left(\mathbb{I}_{n}-Q\right) u \in C^{p+1}\left([0, \tau] ; \mathbb{R}^{n}\right)$ and $u^{1}=Q u \in C\left([0, \tau] ; \mathbb{R}^{n}\right)$ there exists a unique solution $x=x(t)$ to problem (1), (3), which, in addition, is given by

$$
x(t)=-\sum_{q=0}^{p} H^{q} M^{\prime}\left(\mathbb{I}_{n}-Q\right) u^{0(q)}(t)+U^{t} x_{0}+\int_{0}^{t} U^{t-s} L^{\prime} Q u^{1}(s) d s .
$$

Here $H=\left(\mathbb{I}_{n}-P\right) M^{\prime} L\left(\mathbb{I}_{n}-P\right)$ and $p=\max \left\{n_{1}, n_{2}, \ldots, n_{k}\right\}$. Since

$$
B^{-1} H B=\left\{J_{n_{1}}, J_{n_{2}}, \ldots, J_{n_{k}}, \mathbb{O}_{r}\right\},
$$

it follows that $H$ is a nilpotent matrix of degree $p$. We can borrow the proof from Section 4 of [17] or give it independently, using Theorem 1.3.

Remark 1.1. The components of the vector function $x=x(t), t \in[0, \tau]$, are meant to be dimensionless quantities characterizing the production of one of the (virtual) variants of construction mix depending on the investment $u=u(t)$ at the moment of time $t=[0, \tau]$. Therefore, it is necessary to include into our mathematical model the system

$$
y=S x,
$$

where the vector function $y=y(t), t \in[0, \tau]$, expresses the quantity of construction mixtures produced in the mass (tonnes) or spatial (cubic meters) units per unit time $t \in[0, \tau]$. Determination of the entries of the matrix $S$ is an engineering problem, which we leave outside the scope of this article. We assume that matrices $L, M$, and $S$ are constructed as a result of experiments. However, we can use the vector function of expenses $u=u(t)$ and the vector function of resulting construction mixes $y=y(t)$ to obtain the vector function of prices $p=p(t)$ for the units of products. Each component of the vector function of prices is of the form $p_{k}(t)=\frac{y_{k}(t)}{u_{k}(t)}$ for $k=1,2, \ldots, n$ and $t \in[0, \tau]$. Thus, at the moment of time $t=\tau$, when the production is complete, the finite price of a unit of variant $k$ of the construction mixture is $p_{k}(\tau)=\frac{y_{k}(\tau)}{u_{k}(\tau)}$, for $k=1,2, \ldots, n$.

\section{Mathematical Modelling of the Production of $n$ Construction Mixes with Prescribed Properties}

Let us continue the constructing the mathematical model for production of construction mixtures with prescribed properties. To explain our understanding of 
prescribed properties of construction mixes, introduce the space of production states $\mathfrak{X}=\left\{x, \dot{x} \in L_{2}\left((0, \tau), \mathbb{R}^{n}\right)\right\}$ for some fixed $\tau \in \mathbb{R}_{+}$. As we indicated in the introduction, the components of the vector functions $x \in \mathfrak{X}$ are dimensionless, and their relation to the vector function $u=u(t)$ of production expenses is expressed by equation (1), which, in turn, is constructed experimentally. Only upon finding (1), verifying that $M$ is an $L$ regular matrix, and determining the number $p \in\{0\} \cup \mathbb{N}$, we can define the space of financial expenses $\mathfrak{U}=\left\{u, u^{(p+1)} \in L_{2}\left((0, \tau), \mathbb{R}^{n}\right)\right\}$. Refer to a vector function $x \in \mathfrak{X}$ satisfying almost everywhere on $(0, \tau)$ system (1) for some $u \in \mathfrak{U}$ as a strong solution to this system. Call the strong solution $x=x(t)$ to (1) a strong solution to problem (1), (3) for some $x_{0} \in \mathbb{R}^{n}$ whenever it also satisfies the Showalter-Sidorov condition (3). By the Sobolev embedding theorem, the components of the vector functions $x \in \mathfrak{X}$ are absolutely continuous on $[0, \tau]$; therefore, the Showalter-Sidorov condition is well-posed in this case.

Theorem 2.1. If $M$ is an L-regular matrix then for all $x_{0} \in \mathbb{R}^{n}$ and $u \in \mathfrak{U}$ there exists a unique strong solution $x=x(t)$, for $t \in[0, \tau]$, to problem (1), (3), which, in addition, is given by (4).

A proof of Theorem 2.1 follows directly from Theorem 1.4. Moreover, it is not difficult to give an independent proof. We will continue construction of the mathematical model, but let us firstly explain what we mean by the prescribed properties of construction mixes. Unfortunately, in the framework of our model we cannot account for the full variety of properties of construction mixes like, for instance, strength, water resistance, temperature resistance, and so forth, separately. We have only a single integral characteristic, the cost (per unit) of the product at almost every moment of time. Certainly, this characteristic is sufficiently universal and can indirectly represent every combination of prescribed properties. Nevertheless, we are ready to have discussions with the experts in construction mixes aiming to make our mathematical model more adequate to their requirements. Therefore, we introduce the main detail of our mathematical model, the penalty functional

$$
\begin{aligned}
& J(u)=\alpha \sum_{q=0}^{1} \int_{0}^{\tau} \sum_{k=1}^{n}\left\{\left[\left(p_{k}(t)-p_{k}^{\circ}(t)\right) y_{k}(t)\right]^{(q)}\right\}^{2} d t+ \\
& +\beta \sum_{k=0}^{\infty} \int_{0}^{\tau}\left\langle R_{k} u^{(k)}(t), u^{(k)}(t)\right\rangle d t, æ=0,1, \ldots, p+1 .
\end{aligned}
$$

Here $p_{k}=p_{k}(t)$ is the $k$-th component of the vector-function of prices on each (virtual) construction mix, $p_{k}=\frac{u_{k}}{y_{k}}$ (see Remark 1 for details). We find the vector-function of prices $p=\left(p_{1}, p_{2}, \ldots, p_{n}\right)$ in the process of production. In contrast to it, the vector-function of prices $p^{\circ}=\left(p_{1}^{\circ}, p_{2}^{\circ}, \ldots, p_{n}^{\circ}\right)$ is specified at the outset and reflects (in an indirect and integrated way) our prescribed properties of construction mixtures. We obtain the vectorfunction $y=\left(y_{1}, y_{2}, \ldots, y_{n}\right)$ from (4) and (5); each of its components is the quantity of construction mix produced by the moment $t \in[0, \tau]$ expressed in the spatial or mass units. The square matrices $R_{k}$ for $k=0,1, \ldots, æ$ are symmetric and nonnegative by defined. Over all, the second term in the penalty functional $J$ is to control the increase of finances during production. Here we control not only the amounts received, but also the rate, acceleration, and the derivatives up to order $p+1$. We introduce a such strict control here only for the 
completeness of the picture; while conducting simulations, we can replace some $R_{k}$ by the zero matrices (that is, $R_{k}=\mathbb{O}_{n}$ for some $k=0,1, \ldots, æ$ ). In the first term of $J$ we also take into account not only the changes in the states $x=\left(x_{1}, x_{2}, \ldots, x_{n}\right)$ of production, but also their rates. However, here we cannot neglect the rates as yet due to the mathematical properties of the proposed model. Finally, we determine the normalization parameters $\alpha \in(0,1]$ and $\beta=1-\alpha$ in the course of simulations, and $\langle\cdot, \cdot\rangle$ stands for the Euclidean inner product on $\mathbb{R}^{n}$.

We need a closed convex subset $\mathfrak{U}_{a \partial} \subset \mathfrak{U}$, the set of admissible financial expenses. For instance,

$$
\mathfrak{U}_{a \partial}=\{u \in \mathfrak{U}: u(t) \geq 0, t \in[0, \tau]\},
$$

that is, the cone of nonnegative vector-functions in $\mathfrak{U}$. (Recall that a vector-function $u$ : $[0, \tau] \rightarrow \mathbb{R}^{n}$ is called nonnegative whenever all its components are nonnegative functions.) Let us now state the problem of finding the minima of the penalty functional $J$ on $\mathfrak{U}_{a \partial}$, that is,

$$
J(v)=\min _{u \in \mathfrak{U}_{a \partial}} J(u) .
$$

Theorem 2.2. The penalty functional $J$ has a unique minimum point on the set $\mathfrak{U}_{a \partial}$ of admissible financial expenses.

Indeed, the set $\mathfrak{U}_{a \partial}$ is convex and closed; consequently, it is weakly closed. The functional $J$ is convex and continuous, and so by Mazur's theorem there exists a unique point $v \in \mathfrak{U}_{a \partial}$ such that (6) holds. Insert this vector function $v=v(t)$, for $t \in[0, \tau]$, into (4) instead of $u(t)$, and then insert the result into (5). This yields $n$ (virtual) construction mixes whose properties are close to those prescribed.

\section{References}

1. Sviridyuk G.A., Brychev S.V. Numerical Solution of Systems of Equations of Leontief Type. Russian Mathematics (Izvestiya VUZ. Matematika), 2003, vol. 47, no. 8, pp. 44-50.

2. Brychev S.V. Issledovanie matematicheskoy modeli ekonomiki kommunal'nogo khozyaystva malykh gorodov [Study of Mathematical Models of Economics and Public Utilities in Small Towns. The Dissertation for Scientific Degree of the Kandidat of Physical and Mathematical Sciences]. Chelyabinsk, 2002.

3. Sviridyuk G.A., Keller A.V. On the Numerical Solution Convergence of Optimal Control Problems for Leontief Type System. Vestn. Samar. Gos. Tekhn. Univ. Ser. Fiz.-Mat. Nauki, 2011, no. 2, pp. 24-33. (in Russian) DOI:10.14498/vsgtu951

4. Keller A.V., Nazarova E.I. Optimal Measuring Problem: the Computation Solution, the Program Algorithm. News of Irkutsk State University. Series: Mathematics, 2011, vol. 4, no. 3, pp. $74-82$.

5. Keller A.V. Numerical Solution of the Optimal Control Problem for Degenerate Linear System of Equations with Showalter - Sidorov Initial Conditions. Bulletin of the South Ural State University. Series: Mathematical Modelling, Programming \& Computer Software, 2008, no. 27 (127), pp. 50-56. (in Russian)

6. Keller A.V. Chislennoe issledovanie zadach optimal'nogo upravleniya dlya modeley leont'evskogo tipa [Numerical Reseach of Optimal Control Problem for Leontieff Type Models. The Dissertation for Scientific Degree of the Doctor of Physical and Mathematical Sciences]. Chelyabinsk, South Ural State University, 2011. 252 p. (in Russian) 
7. Shestakov A.L. Dynamic Error Correction Transducer Linear Filter-Based Sensor Model. Izvestiya VUZ. Priborostroenie, 1991, vol. 34, no. 4, pp. 8-13. (in Russian)

8. Shestakov A.L., Sviridyuk G.A. A new Approach to Measurement of Dynamically Perturbed Signals. Bulletin of the South Ural State University. Series: Mathematical Modelling, Programming 63 Computer Software, 2010, no. 16 (192), pp. 116-120. (in Russian)

9. Shestakov A.L., Keller A.V., Sviridyuk G.A. The Theory of Optimal Measurements. Journal of Computational and Engineering Mathematics, 2014, vol. 1, no. 1, pp. 3-16.

10. Shestakov A., Sagadeeva M., Sviridyuk G. Reconstruction of a Dynamically Distorted Signal with Respect to the Measuring Transducer Degradation. Applied Mathematical Sciences, 2014 , vol. 8 , no. $41-44$, pp. $2125-2130$.

11. Showalter R.E. The Sobolev Type Equations. I (II). Appl. Anal., 1975, vol. 5, no. 1 (no 2), pp. 15-22 (pp. 81-99).

12. Sviridyuk G.A., Keller A.V. Invariant Spaces and Dichotomies of Solutions of a Class of Linear Equations of Sobolev Type. Russian Mathematics (Izvestiya VUZ. Matematika), 1997, vol. 41, no. 5, pp. 57-65.

13. Favini A., Yagi A. Degenerate Differential Equations in Banach Spaces. N.-Y., Basel, Hong Kong, Marcel Dekker, Inc, 1999. 236 p.

14. Pyatkov S.G. Operator Theory. Nonclassical Problems. Utrecht, Boston, Köln, Tokyo, VSP, 2002. DOI:10.1515/9783110900163

15. Sidorov N., Loginov B., Sinithyn A., Falaleev M. Lyapunov-Shmidt Methods in Nonlinear Analysis and Applications. Dordrecht, Boston, London, Kluwer Academic Publishers, 2002. 548 p. DOI:10.1007/978-94-017-2122-6

16. Demidenko G.V., Uspenskii S.V. Partial Differential Equations and Systems not Solvable with Respect to the Highest-Order Deriative. N.-Y.; Basel; Hong Kong: Marcel Dekker, Inc., 2003.

17. Sviridyuk G.A., Fedorov V.E. Linear Sobolev Type Equations and Degenerate Semigroups of Operators. Utrecht, Boston, Köln, Tokyo, VSP, 2003. DOI:10.1515/9783110915501

18. Al'shin A.B., Korpusov,M.O., Sveshnikov A.G., Al'shin A.B. Blow-up in Nonlinear Sobolev Type Equations. Berlin, Walter de Gruyter GmbH\& Co.KG, 2011.

19. Zamyshlyaeva A.A. Linear Sobolev Type Equations of High Order. Chelyabinsk, Publ. Center of the South Ural State University, 2012. (in Russian)

20. Zagrebina S.A., Moskvicheva P.O. Ustoychivost' v modelyakh Khoffa [Stability in Hoff Models]. Saarbrucken: LAMBERT Academic Publishing, 2012. (in Russian)

21. Manakova N.A. Optimal Control Problem for the Sobolev Type Equations. Chelyabinsk, Publ. Center of the South Ural State University, 2012. (in Russian)

22. Sagadeeva M.A. Dichotomy of Solutions of Linear Sobolev Type Equations. Chelyabinsk, Publ. Center of the South Ural State University, 2012. (in Russian)

23. Fedorov V.E. Holomorphic Solution Semigroups for Sobolev-Type Equations in Locally Convex Spaces. Sbornik: Mathematics, 2004, vol. 195, no. 8, pp. 1205-1234. DOI:10.1070/SM2004v195n08ABEH000841

24. Sviridyuk G.A., Al Delfi D.K. [Theorem on Splitting Quasi-Banach Spaces]. Matematicheskie zametki SVFU, 2013, vol. 20, no. 2, pp. 180-185. (in Russian)

25. Boyarintsev Yu.E. Metody resheniya vyrozhdennykh sistem obyknovennykh differentsial'nykh uravneniy [Methods of Solving Singular Systems of Ordinary Differential Equations]. Novosibirsk, Nauka, 1988.

26. Boyarintsev Yu.E., Chistyakov V.F. Algebro-differentsial'nye uravneniya. Metody resheniya i issledovaniya [Differential-Algebraic Equations. Solution Methods and Research]. Novosibirsk, Nauka, 1998.

27. Sviridyuk G.A., Zagrebina S.A. The Showalter - Sidorov Problem as Phenomena of the Sobolev-Type Equations. News of Irkutsk State University. Series: Mathematics, 2010, vol. 3, no. 1, pp. 51-72. (in Russian) 
28. Gantmacher F.R. The Theory of Matrices. N.Y., Chelsea Publishing Company, 1959.

Received October 14, 2014

УДК 517.9

DOI: $10.14529 / \mathrm{mmp} 150108$

\title{
МАТЕМАТИЧЕСКОЕ МОДЕЛИРОВАНИЕ СОСТАВА СТРОИТЕЛЬНЫХ СМЕСЕЙ С ЗАДАННЫМИ СВОЙСТВАМИ
}

\author{
А.Л. Шестаков, Г.А. Свиридюк, М.Д. Бутакова
}

\begin{abstract}
Предложен метод математического моделирования состава строительных смесей с заданными свойствами. В основе метода лежит теория оптимального управления системами уравнений леонтьевского типа. Уравнения леонтьевского типа первоначально возникли как обобщения известной экономической модели В. Леонтьева «затраты - выпуск» с учетом запасов. Затем они с успехом были использованы в динамических измерениях, породив тем самым теорию оптимальных измерений. Во введении на описательном уровне обсуждается идеология предлагаемой модели. Для иллюстрации использован пример составления простейших бетонных смесей. В первом параграфе моделируется процесс производства однотипных строительных смесей (например, бетонных смесей) в зависимости от финансовых вложений. В результате определяется цена единицы произведенной продукции. Во втором параграфе закладывается основа для будущего построения численных алгоритмов, конструирования комплексов программ и проведения вычислительных экспериментов. Помимо этого дается объяснение заданных свойств строительных смесей как оптимальных по затратам.
\end{abstract}

Ключевые слова: системы леонтвевкого типа; производство строительных смесей.

\section{Литература}

1. Свиридюк, Г.А. Численное решение систем уравнений леонтьевского типа / Г.А. Свиридюк, С.В. Брычев // Известия вузов. Математика. - 2003. - № 8. - С. 46-52.

2. Брычев, С.В. Исследование математической модели экономики коммунального хозяйства малых городов: дис. ... канд. физ.-мат. наук / С.В. Брычев. - Челябинск, 2002.

3. Свиридюк, Г.А. О сходимости численного решения задач оптимального управления для систем уравнений леонтьевского типа / Г.А. Свиридюк, А.В. Келлер // Вестник Самарского государственного технического университета. Серия: Физико-математические науки. - 2011. - №2. - С. 24-33.

4. Келлер, А.В. Задача оптимального измерения: численное решение, алгоритм программы / А.В. Келлер, Е.И. Назарова // Известия Иркутского государственного университета. Серия: Математика. - 2011. - №3. - С. 74-82.

5. Келлер, А.В. Численное решение задачи оптимального управления вырожденной линейной системой уравнений с начальными условиями Шоуолтера - Сидорова / А.В. Келлер // Вестник ЮУрГУ. Серия: Математическое моделирование и программирование. 2008. - № 27 (127), вып. 2. - С. 50-56.

6. Келлер, А.В. Численное исследование задач оптимального управления для моделей леонтьевского типа: дис. ... д-ра физ.-мат. наук / А.В. Келлер. - Челябинск, 2011. 
7. Шестаков, А.Л. Коррекция динамической погрешности измерительного преобразователя линейным фильтром на основе модели датчика/ А.Л. Шестаков // Известия высших учебных заведений. Приборостроение. - 1991. - Т. 34, №4. - С. 8-13.

8. Шестаков, А.Л. Новый подход к измерению динамически искаженных сигналов / А.Л. Шестаков, Г.А. Свиридюк // Вестник ЮУрГУ. Серия: Математическое моделирование и программирование. - 2010. - № 16 (192), вып. 5. - С. 116-120.

9. Shestakov, A.L. The Theory of Optimal Measurements / A.L. Shestakov, A.V. Keller, G.A. Sviridyuk // Journal of Computational and Engineering Mathematics. - 2014. - V. 1, № 1. - P. 3-16.

10. Shestakov, A. Reconstruction of a Dynamically Distorted Signal with Respect to the Measuring Transducer Degradation / A. Shestakov, M. Sagadeeva, G. Sviridyuk // Applied Mathematical Sciences. - 2014. - V. 8, №41-44. - P. 2125-2130.

11. Showalter, R.E. The Sobolev Type Equations. I (II)/ R.E. Showalter // Appl. Anal. - 1975. V. 5, № 1 (№ 2). - P. 15-22 (Р. 81-99).

12. Свиридюк, Г.А. Инвариантные пространства и дихотомии решений одного класса линейных уравнений типа Соболева / Г.А. Свиридюк, А.В. Келлер // Известия вузов. Математика. - 1997. - № 5. - С. 60-68.

13. Favini, A. Degenerate Differential Equations in Banach Spaces / A. Favini, A. Yagi. - N.-Y.; Basel; Hong Kong: Marcel Dekker, Inc, 1999. - 236 p.

14. Pyatkov, S.G. Operator Theory. Nonclassical Problems / S.G. Pyatkov. - Utrecht; Boston; Köln; Tokyo: VSP, 2002.

15. Lyapunov-Shmidt Methods in Nonlinear Analysis and Applications / N. Sidorov, B. Loginov, A. Sinithyn and M. Falaleev. - Dordrecht; Boston; London: Kluwer Academic Publishers, 2002. -548 p.

16. Demidenko, G.V. Partial Differential Equations and Systems not Solvable with Respect to the Highest - Order Deriative / G.V. Demidenko, S.V. Uspenskii. - N.-Y.; Basel; Hong Kong: Marcel Dekker, Inc., 2003.

17. Sviridyuk, G.A. Linear Sobolev Type Equations and Degenerate Semigroups of Operators / G.A. Sviridyuk, V.E. Fedorov. - Utrecht; Boston; Köln; Tokyo: VSP, 2003.

18. Al'shin, A.B. Blow-up in Nonlinear Sobolev Type Equations / A.B. Al'shin, M.O. Korpusov, A.G. Sveshnikov. - Berlin: Walter de Gruyter GmbH\& Co.KG, 2011.

19. Замышляева, А.А. Линейные уравнения соболевского типа высокого порядка / А.А. Замышляева. - Челябинск: Изд. центр ЮУрГУ, 2012. - 107 с.

20. Загребина, С.А. Устойчивость в моделях Хоффа / С.А. Загребина, П.О. Москвичева. Saarbrucken: LAMBERT Academic Publishing, 2012. - 87 c.

21. Манакова, Н.А. Задачи оптимального управления для уравнений соболевского типа / Н.А. Манакова. - Челябинск: Изд. центр ЮУрГУ, 2012. - 88 с.

22. Сагадеева, М.А. Дихотомии решений линейных уравнений соболевского типа / М.А. Сагадеева. - Челябинск: Изд. центр ЮУрГУ, 2012. - 139 с.

23. Федоров, В.Е. Голоморфные разрешающие полугруппы уравнений соболевского типа в локально выпуклых пространствах / В.Е. Федоров // Математический сборник. 2004. - Т. 195, № 8. - С. 131-160.

24. Свиридюк, Г.А. Теорема о расщеплении в квазибанаховых пространствах / Г.А. Свиридюк, Д.К. Аль-Делфи // Математические заметки СВФУ. - 2013. - Т. 20, № 2. C. $180-185$.

25. Бояринцев, Ю.Е. Методы решения вырожденных систем обыкновенных дифференциальных уравнений / Ю.Е. Бояринцев. - Новосибирск: Наука, 1988.

26. Бояринцев, Ю.Е. Алгебро-дифференциальные уравнения. Методы решения и исследования / Ю.Е. Бояринцев, В.Ф. Чистяков. - Новосибирск: Наука, 1998. 
27. Свиридюк, Г.А. Задача Шоуолтера - Сидорова как феномен уравнений соболевского типа / Г.А. Свиридюк, С.А. Загребина // Известия Иркутского государственного университета. Серия: Математика. - 2010. - Т. 3, № 1. - С. 104-125.

28. Гантмахер, Ф.Р. Теория матриц / Ф.Р. Гантмахер. - М: Физматлит, 2004.

Александр Леонидович Шестаков, доктор технических наук, профессор, кафедра «Информационно-измерительная техника», Южно-Уральский государственный университет (г. Челябинск, Российская Федерация), admin@susu.ac.ru.

Георгий Анатольевич Свиридюк, доктор физико-математических наук, професcop, кафедра «Уравнения математической физики», Южно-Уральский государственный университет (г. Челябинск, Российская Федерация), sviridyuk@susu.ac.ru.

Марина Дмитриевна Бутакова, кандидат технических наук, доцент, кафедра «Строительные материалы», Южно-Уральский государственный университет (г. Челябинск, Российская Федерация), butakovamd@susu.ac.ru.

Поступила в редакиию 14 октября 20142. 